\title{
Case of drug reaction with eosinophilia and systemic symptoms secondary to vancomycin
}

\author{
Natalia Chamorro-Pareja, ${ }^{1}$ Arthi Patel, ${ }^{2}$ George Youngberg, ${ }^{2}$ Alexei Gonzalez-Estrada ${ }^{3}$
}

'Department of Medicine, Division of Pulmonary, Allergy and Sleep Medicine, Mayo Clinic's Campus in Florida, Jacksonville, Florida, USA ${ }^{2}$ Pathology, East Tennessee State University James H Quillen College of Medicine, Johnson City, Tennessee, USA ${ }^{3}$ Division of Allergy and Clinical Immunology, Department of Medicine, East Tennessee State University James H Quillen College of Medicine, Johnson City, Tennessee, USA

\section{Correspondence to}

Dr Alexei Gonzalez-Estrada, gonzalez.alexei@mayo.edu

Accepted 20 September 2018

Check for updates

(C) BMJ Publishing Group Limited 2018. No commercial re-use. See rights and permissions. Published by BMJ.

\begin{tabular}{l}
\hline To cite: Chamorro-Pareja N, \\
Patel A, Youngberg G, et al. \\
BMJ Case Rep Published \\
Online First: [please \\
include Day Month Year]. \\
doi:10.1136/bcr-2018- \\
227378 \\
\hline
\end{tabular}

\section{DESCRIPTION}

A 38-year-old man with a medical history of hepatitis C presented with a 2-day pruritic rash. It started on his back and generalised within 2 days. The patient had been on vancomycin for the last 3 weeks due to a recent diagnosis of osteomyelitis. He was not taking other medications. On physical examination, a diffuse blanching maculopapular exanthema was noted (figure $1 \mathrm{~A}$ and $\mathrm{B}$ ) associated to facial angioedema and palpable axillary and inguinal lymph nodes. Laboratory evaluation was relevant for leucocytosis with neutrophilia and eosinophilia, mild elevation of liver function tests and peripheral blood smear revealing atypical lymphocytes (figure 2). Skin biopsy demonstrated superficial perivascular dermatitis with papillary dermal oedema (figure 3). Diagnosis of drug reaction with eosinophilia and systemic symptoms (DRESS) was made. Vancomycin was suspended and daptomycin was initiated. He also received treatment with high-dose antihistamines and systemic corticosteroids. Follow-up showed resolution of the rash.

DRESS syndrome is a rare but potentially life-threatening condition characterised by a delayed multisystem compromise following the administration of a drug. ${ }^{1}$ Symptoms include rash, fever, haematological abnormalities (ie, leucocytosis, eosinophilia and atypical lymphocytosis), lymphadenopathy and internal organ involvement, most commonly being involved the liver or kidneys. ${ }^{2}$ The rash is usually diffuse and maculopapular, but other dermatological presentations are common, including vesicles, pustules and bullae. ${ }^{1}$ DRESS syndrome most commonly occurs after treatment with anticonvulsants, but it also occurs with other types of drugs including vancomycin. It typically develops 2-6 weeks after the initiation of the drug. ${ }^{3}$ There are no validated diagnostic criteria, but the RegiSCAR score system is the most commonly used. The following criteria are included: fever $\geq 38.5^{\circ} \mathrm{C}$, enlarged lymph nodes $(>1 \mathrm{~cm}$ size in at least two sites), eosinophilia

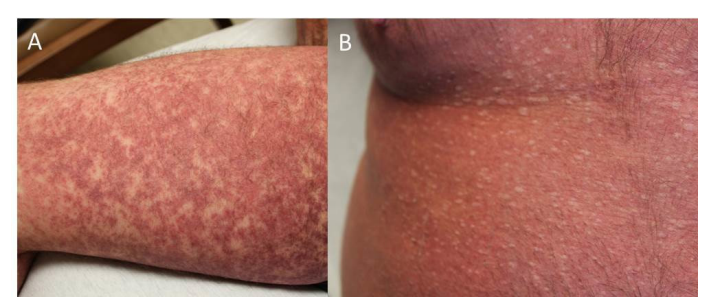

Figure 1 Diffuse blanching maculopapular exanthema located in thigh $(A)$ and abdomen $(B)$.

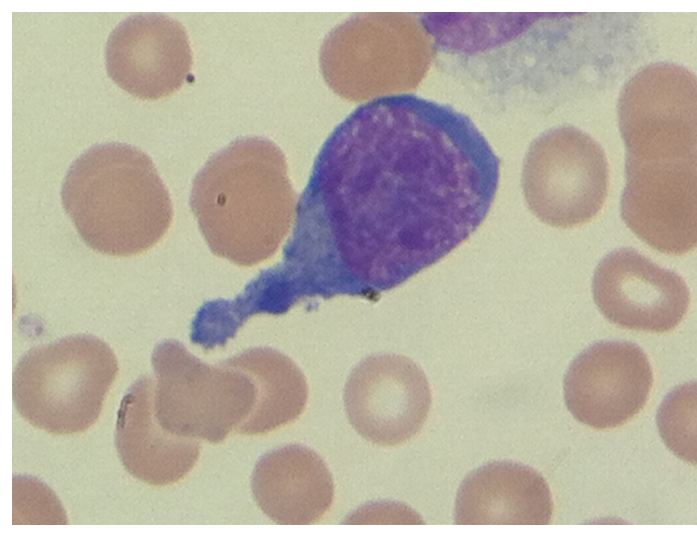

Figure 2 Peripheral blood smear showing atypical lymphocytes.

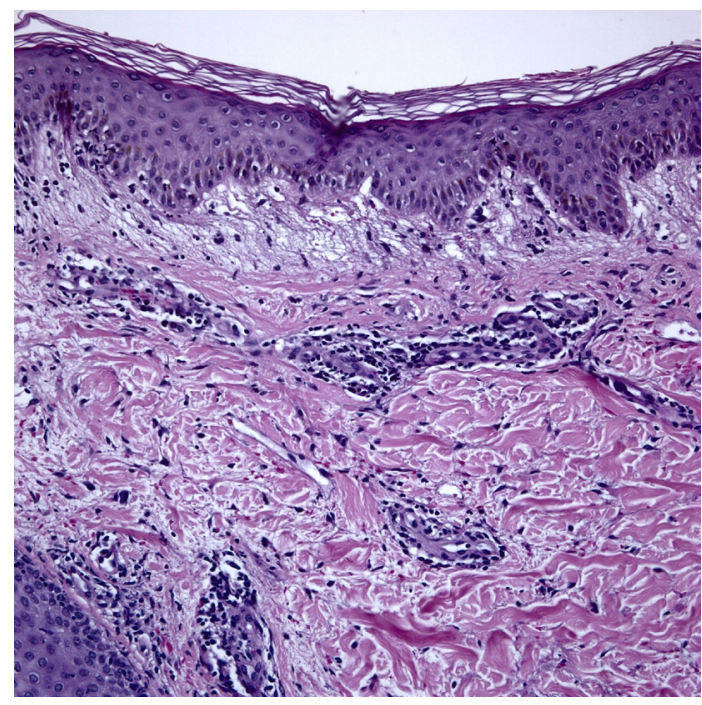

Figure 3 Skin biopsy demonstrating superficial perivascular dermatitis with papillary dermal oedema.

( $\geq 700$ or $\geq 10 \%$ ), atypical lymphocytes, rash (with scaling, angioedema, purpura, infiltration) which comprises $\geq 50 \%$ of body surface area and

\section{Learning points}

Drug reaction with eosinophilia and systemic symptoms syndrome is a potentially fatal reaction to drugs.

- Symptoms include rash, fever, haematological abnormalities and organ involvement.

- It most commonly occurs secondary to anticonvulsants but can also be secondary to other type of drugs, including vancomycin. 
involvement of at least one internal organ. ${ }^{2}$ Histopathological analysis can reveal a combination of lymphocytic exocytosis, epidermal spongiosis, interface vacuolisation, papillary oedema (seen in our patient), and perivascular lymphocytic and eosinophilic infiltration. ${ }^{2}$ Stopping the triggering drug is the most important step when managing patients with DRESS syndrome. Treatment also comprises supportive measures, corticosteroids and immunosuppressants. ${ }^{3}$

Contributors NC-P: reporting, conception and design, analysis and interpretation of data. AP: reporting, conception and design, acquisition of data or analysis and interpretation of data. GY: planning, conduct, reporting, conception and design, acquisition of data or analysis and interpretation of data. AG-E: planning, conduct, reporting, conception and design, acquisition of data or analysis and interpretation of data.
Funding The authors have not declared a specific grant for this research from any funding agency in the public, commercial or not-for-profit sectors.

Competing interests None declared.

Patient consent Obtained.

Provenance and peer review Not commissioned; externally peer reviewed.

\section{REFERENCES}

1 Young $\mathrm{S}$, Ojaimi S, Dunckley $\mathrm{H}$, et al. Vancomycin-associated drug reaction with eosinophilia and systemic symptoms syndrome. Intern Med J 2014;44:694-6.

2 Chi MH, Hui RC, Yang CH, et al. Histopathological analysis and clinical correlation of drug reaction with eosinophilia and systemic symptoms (DRESS). Br J Dermatol 2014;170:866-73.

3 Sultan SJ, Sameem F, Ashraf M. Drug reaction with eosinophilia and systemic symptoms: manifestations, treatment, and outcome in 17 patients. Int I Dermatol 2015;54:537-42.

Copyright 2018 BMJ Publishing Group. All rights reserved. For permission to reuse any of this content visit http://group.bmj.com/group/rights-licensing/permissions.

BMJ Case Report Fellows may re-use this article for personal use and teaching without any further permission.

Become a Fellow of BMJ Case Reports today and you can:

- Submit as many cases as you like

- Enjoy fast sympathetic peer review and rapid publication of accepted articles

- Access all the published articles

Re-use any of the published material for personal use and teaching without further permission

For information on Institutional Fellowships contact consortiasales@bmjgroup.com

Visit casereports.bmj.com for more articles like this and to become a Fellow 